\title{
Voice and daytime calling of Scops Owls (Otus scops)
}

\author{
Anita Mikkola \& Heimo Mikkola*
}

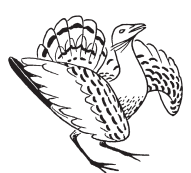

Anita Mikkola \& Heimo Mikkola 2015. Voice and daytime calling of Scops Owls (Otus scops). - Ornis Hungarica 23(2): 49-52.

Abstract The Scops Owl (Otus scops) is one of the least studied owls in Europe and its loud and monotonous calls are not well documented. This paper summarises published alarm-like calls and presents data on daytime calling recorded in Lesencetomaj, Hungary between $9^{\text {th }}$ and $17^{\text {th }}$ September 2012. Calls were similar to the sound of an alarm on a reversing truck. The bird was most active around midday (11-13 hrs) and in the afternoons between 15-17 hrs. No calling occurred before 09.00 or after 19.15 o'clock. Weather affected the intensity of calls and particularly high autumn temperatures are suggested as a possible reason for this unusual activity.

Keywords: Scops Owl, Otus scops, alarm call, diurnal vocal activity

Összefoglalás A füleskuvik (Otus scops) egyike Európa legkevésbé kutatott bagolyfajainak. Messzire hangzó, monoton jelzőhangja csak kevés figyelmet kapott ezidáig. A jelen közlemény irodalmi adatokat közöl a faj jelző és vészjelző hangjáról, és adatokat közöl nappali hívóhang észlelésekről, amelyeket Magyarországon, Lesencetomajon, 2012. szeptember 9. és 17. között figyeltek meg a szerzők. A vészjelző hang egy teherautó tolató jelzőhangjához volt hasonlítható. A megfigyelt példány 11:00 és 13:00 óra között, illetve délután 15:00 és 17:00 óra között volt a legaktívabb. Nem lehetett hívóhangot észlelni reggel 09:00 előtt és este 19:15 után. A szokatlan territórium jelző hívóhang hallatását feltehetően az időjárás, különösen a magas szeptemberi hőmérséklet befolyásolhatta.

Kulcsszavak: füleskuvik, Otus scops, hívóhang, nappali hangadás

University of Eastern Finland, Kuopio Campus, P. O. Box 1627, FIN-70211 Kuopio, Finland,

e-mail:heimomikkola@yahoo.co.uk

*corresponding author

\section{Introduction}

Most of Europe's Scops Owl (Otus scops) population is fully migratory, spending the winter months in African savannahs, and migrating north in spring to parts of France, Germany, Austria, Switzerland, Ukraine, Hungary, Czech Republic. Populations in southern Spain, southern Italy, southern Greece and most of the Mediterranean islands tend to be resident (Hagemeijer \& Blair 1997). Population figures (20022007) are only available for Central Eu- rope: Germany (3 pairs), Switzerland (1215), Austria (40-60), Slovakia (40-80), Czech Republic (0-4), Hungary (500-600) and Slovenia (500-800) (Mebs \& Scherzinger 2008). There are contrasting fortunes for this bird though, for in some countries such as Switzerland, numbers plummeted from 30 pairs to 13 during the period 19821997 (Schweizerische Vogelwarte), whereas during a similar period an increase was noted in Hungary (Bagyura \& Haraszthy 2004) and Slovenia (Tome 1998). 


\section{Voice}

This bird is one of lesser known owl species, particularly its call, which may well be misinterpreted by the unfamiliar observer.

Within the literature there are a number of interesting comments on the voice of Scops Owl which we would like to bring to the reader's attention. This may help facilitate more records of this notoriously difficult bird to observe - even when close by. As one trip report so well puts it: 'I hear five Scops Owls in Cyprus, but still not seen one though I was right below one calling and responding to me - how frustrating. I still think the call is best described as similar to a submarine sonar echo' (Bickerton 1995).

In the UK there are two well-known incidents caused by the alarm-like voice of the Scops Owl. From $12^{\text {th }}$ May to at least $14^{\text {th }} \mathrm{Ju}-$ ly, 1980, the loud and monotonous call of the owl led some of the dummer residents of Hampshire to complain to British Telecom (or rather the GPO as it was then) about the noise until someone pointed out that it was a Scops Owl (Rogers et al. 1981)!

In the spring of 2006 the residents of the Oxfordshire village of Thrupp, were woken for weeks (some say from as early as $21^{\text {st }}$ April until $30^{\text {th }}$ June) by the repeated sound of what they thought was a faulty alarm on a canal boat or a car alarm. This noise however did not switch itself off as car alarms are required by law to do and eventually the guilty party turned out to be the first accepted record of a Eurasian Scops Owl recorded in Oxford- shire (Fraser et al. 2007). As the residents of Thrupp discovered, when it is calling for a mate this species can deliver its call up to 26 times a minute, and at a pitch of $1.35 \mathrm{Khz}$ (Editor 2006).

\section{Daytime calling}

Calling by Scops Owl is considered by most authorities to take place nocturnally, although nearly 80 years ago Witherby et al. (1938), noted that it occasionally called by day. More recently though, this behaviour seems to have become more common, in some places.

The regular occurrence of daytime hooting of Scops Owl was first noted in Kazakhstan where a Scops Owl was discovered calling during the day along the Almaty Canal on the $28^{\text {th }}$ May, 1999 (Taylor 1999). More recently we have heard Scops Owl calling regularly during the day in Lesencetomaj, Hungary next to Lake Balaton.

First time we heard Scops Owl's daytime calls during one day on $23^{\text {rd }}$ September 2010 and again $11^{\text {th }}-23^{\text {rd }}$ September 2011, but no systematic records were kept before 2012. Then calling was noted on several days between $9^{\text {th }}$ and $17^{\text {th }}$ September 2012. There was no opportunity to listen the autumn calls before the $23^{\text {rd }}$ in $2010,11^{\text {th }}$ in 2011 and $9^{\text {th }}$ September in 2012 so the earliest start of the calls is not known. It seems from our observations that after the $23^{\text {rd }}$ both in 2010 and 2011 and after $17^{\text {th }}$ September 2012 the owls(s) presumably left for Africa. Unfortunately we

\begin{tabular}{|l|c|c|c|c|c|c|}
\hline Time & $09-11$ & $11-13$ & $13-15$ & $15-17$ & $17-19$ & $19-20$ \\
\hline Calls & $14 \%$ & $25 \%$ & $18 \%$ & $22 \%$ & $20 \%$ & $1 \%$ \\
\hline
\end{tabular}

Table 1. Timed sequences of the 411 recorded calls in Lesencetomaj, Hungary between $9^{\text {th }}$ and $17^{\text {th }}$ September 2012.

1. táblázat A 411 feljegyzett hang időeloszlása (Lesencetomaj, Magyarország, 2012. szeptember 9-17.) 
were not able to visit the study site during the autumns of 2013-2014 but intend to do so again in 2015.

Typically, the owl was not seen even though it was calling close by. Its calls could have been mistaken for that of the Midwife Toad (Alytes obstretricans) as has often been the case in the past (Mikkola 1983). However, we were fortunate in that the bird continually shifted its calling place over an area encompassing $200 \mathrm{~m}$, so the likelihood of it being a toad was eliminated. Calling was similar to that of the alarm on a reversing truck, but fortunately there were no trucks in the area.

The bird was most active around midday (11-13 hrs) and in the afternoons between $15-17 \mathrm{hrs}$. No calling took place before 09.00 or after 19.15 o'clock although they were listened for in the early mornings, late evenings and often also during the night.

Call frequency was 0 to 4 calls per minute and when continuous calling took place it did so at a rate of at least 2 calls per minute. A call usually contained 14 very rapidly (ca. 1 per second) repeated 'toots' but during less active calling the rate fell to eleven toots/call. The opportunity also arose to record changes in call times due to the onset of shortening days, with calling in early September lasting later in to the evenings (19.15 vs. 18.45 ) and started earlier in the morning (09.00 vs. 10.15). A cold spell of weather between the $13^{\text {th }}$ and $15^{\text {th }}$ September, when the temperature fell sharply within a few hours from +30 to $+8^{\circ} \mathrm{C}$, silenced the owl completely. It did not start to call again before the temperature had risen to over $20^{\circ} \mathrm{C}$. Similarly in 2011 sudden temperature drop from 29 to $13{ }^{\circ} \mathrm{C}$ on $19^{\text {th }}$ September stopped the calls until $23^{\text {rd }}$ September when the last call was heard in that year.

Early September 2011 and 2012 were very hot and dry in Hungary. This may explain why a Scops Owl was calling during the day- time. Similar late autumn and even winter calling has been described from Mediterranean islands but mainly only during the evening (König 1970, Glutz von Blotzheim \& Bauer 1980, Exner \& Griesch 2000). In February 1991 three pairs of Scops Owls (of the race cyprius) were studied in Cyprus, and only on two occasions, calls were heard in the middle of the day (Gassick 1993).

We tentatively suggest that this strange behaviour is on the increase, although it is far from widespread, with isolated pockets turning up here and there. It is interesting that another strictly nocturnal owl, Tawny Owl (Strix aluco) has started to call more often during the daytime. A recent British survey has shown that not only did Tawny Owls call more frequently in the mid-day period; they also called more frequently when the sun shone. Of those records where the weather conditions were described, 58\% (131) reported that the calling occurred in bright sunshine (Martin \& Mikkola 2013a, b, 2014).

In the case of the Tawny Owl the spring peak in daylight calling is seemingly clearly associated with the breeding season; interestingly, this contrasts with the well-established autumn peak in nocturnal calling by Tawny Owls, which is associated with the re-establishment of territories after the end of the breeding season. Unfortunately this comparison with a sedentary Tawny Owl does not explain the behaviour of Scops Owls especially during their pre-migration time, if not assuming that the young male Scops Owls erroneously start announcing their territory during the exceptionally warm autumn periods.

\section{Acknowledgement}

We would like to express our gratitude to referees. 


\section{References}

Bagyura, J. \& Haraszthy, L. 2004. The status of birds of prey and owls in Hungary. - In: Chancellor, R. \& Meyburg, B-U. (eds.) Raptors Worldwide. WWGBP, Budapest, pp. 890

Bickerton, D. 1995. Cyprus Trip Report $8^{\text {th }}-21^{\text {st }}$ April 1995. - Ornithological Society of the Middle East, the Caucasus and Central Asia, pp. 5-9.

Editor 2006. Noises in the Night Disrupt Thrupp! International Owl Society's Tyto magazine, p. 3.

Exner, S. \& Griesch, J. 2000. Spätsommerliche Gesansaktivität korsischer Zwergohreulen im Gebirge und an der Küste [Late summer calling activity of Scops Owl in Corsican mountains and coast].Ornithologische Mitteilungen 52: 30-31. (in German)

Fraser, P. A. \& the Rarities Committee 2007. Report on rare birds in Britain 2006. - British Birds 100: 694-754.

Gassick, J. C. 1993. Call patterns of Eurasian Scops Owl. - British Birds 86: 271.

Glutz von Blotzheim, U. N. \& Bauer, K. M. 1980. Handbuch der Vögel Mitteleuropas, Vol. 9. Columbiformes-Piciformes. - Akademische Verlagsgesellschaft,Wiesbaden, pp. 1148 (in German)

Hagemeijer, E. J. M. \& Blair, M. J. (eds.) 1997. The EEBC Atlas of European breeding birds: their distribution and abundance. - T \& AD Poyser, London, pp. 903

König, C. 1970. Herbstbalz der Zwergohreule (Otus scops) [Autumn calling of the Scops Owl (Otus scops)]. - Ornithologische Mitteilungen 22: 4445. (in German)
Martin, J. R. \& Mikkola, H. 2013a Daylight calling by Tawny Owls - an update. - British Birds Home: News and Comment p. 28.

Martin, J. R. \& Mikkola, H. 2013b Day screamers. BBC Wildlife, p. 105.

Martin, J. R. \& Mikkola, H. 2014. The changing face of Britain's Tawny Owls. - British Wildlife 25(6): 391-399.

Mebs, T. \& Scherzinger, W. 2008. Die Eulen Europas (2. Auflage) [The Owls of Europe]. - Kosmos Verlag, Stuttgart, pp. 398 (in German)

Mikkola, H. 1983. Owls of Europe. - T \& AD Poyser, Calton, pp. 397

Rogers, M. J. \& the Rarities Committee 1981. Report on Rare Birds in Great Britain 1980. - British Birds 74: 453-495.

Schweizerische Vogelwarte [Swiss Ornithological Institute]. Seerose 1, - CH 6204 Sempach, Switzerland, pp. 1-2.(in German)

Taylor, D. 1999. Trip Reports. - Kazakhstan May 21June 5, 1999. Ornithological Society of the Middle East, the Caucasus and Central Asia, pp. 7-9.

Tome, D. 1998. Eulen in Slovenien - Status und Verbreitung. - Population Ökologie der Greifvögel und Eulenarten 3: 343-351. (in German)

Witherby, H. F., Jourdain, F. C. R., Ticehurst, N. F. \& Tucker, B. W. 1938. The handbook of British Birds, Vol. 2. - H. F. \& G. Witherby Ltd., London, pp. 511

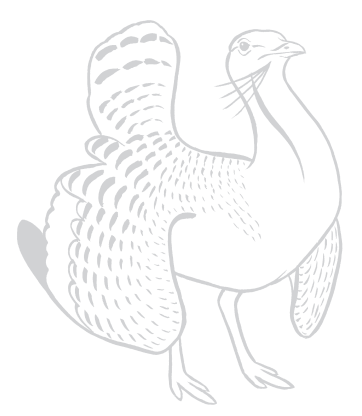

